\title{
Achromobacter denitrificans
}

National Cancer Institute

\section{Source}

National Cancer Institute. Achromobacter denitrificans. NCI Thesaurus. Code C86080.

A species of aerobic, Gram negative bacteria assigned to the phylum Proteobacteria.

This bacteria is motile by flagella, oxidase positive, urease negative, hydrolyzes esculin and is unable to ferment glucose. A. dentrificans is normally found in soil but has been isolated from human clinical specimens. 